\title{
Situation Analysis of Socio Environmental Aspects of Non point Source Water Pollution in Intensively Cultivated Areas of Nuwara Eliya
}

\author{
K.D.M.S.S. Sarathchandra, N.D.K. Dayawansa ${ }^{1 *}$ and M.I.M. Mowjood ${ }^{1}$ \\ Postgraduate Institute of Agriculture \\ University of Peradeniya \\ Sri Lanka
}

\begin{abstract}
Nonpoint source water pollution is one of the most critical pollution problems all over the world. This study was conducted to assess the status of water pollution, prevention and management and to investigate the awareness of farmers about water quality, water pollution and riparian buffer zones in Moonplains and Blackpool in Nuwara Eliya. Surface and shallow groundwater samples were collected representing natural, agricultural landscapes to test pH, Electrical Conductivity, Nitrate and Phosphate. High Electrical Conductivity $(151 \mathrm{dS} / \mathrm{m})$ was reported in cultivated area throughout the study period compared to the forest area. Higher amount of nitrate (32 ppm) was reported in shallow groundwater and lower level of $P$ was observed in both vegetable cultivated areas and natural forest. A questionnaire survey was carried out among 30 farmers to gather information on fertilizer and pesticide usage, agronomic practices and knowledge about the riparian buffer zones. Farmers were selected based on the land proximity to the adjacent water sources. Majority of the Farmers were males and belonged to age group 30-40 years. Eighty percent of the land extent belonged to $0.04-0.2$ ha and above 0.2 ha categories out of which $67 \%$ were in medium slope category. Majority of the lands were owned by the farmers themselves. Irrigation water requirement is mainly supplied through the surface water. Majority (83\%) were aware of the water pollution and knowledge is transferred via generations and not by the education. Nearly $73 \%$ of the respondents were aware on riparian buffer zone as a soil conservation method but not as a water quality improvement method. However, due to landlessness, $43 \%$ of the farmers did not like to maintain the riparian buffer zone, therefore, capacity building, proper farmer awareness on water pollution and need of maintaining a riparian buffer zone are essential to protect water sources in this intensively agricultural area.
\end{abstract}

Keyword: Non point source, riparian buffer zone, up country, water pollution

\section{INTRODUCTION}

All over the world, a considerable fraction of water pollution has been recognized as originating from Non Point Sources (NPS) (Luzio et al., 2004) such as agriculture, silviculture, mining, construction, urban activities and atmospheric deposition (Neary et al., 1989). NPS loading is carried by storm water runoff and percolating water draining

\footnotetext{
1 Department of Agricultural Engineering, Faculty of Agriculture, University of Peradeniya, Sri Lanka.

* Author for correspondence: dammid@pdn.ac.lk
} 
residential, commercial, rural and agricultural areas where many everyday activities add polluting substances to the land (Luzio et al., 2004). It is a challenge to identify and determine the geographic boundaries of the source (Mendelker, 1989). As explained by Ritter and Shirmohammadi, (2001), NPS pollutants such as sediment, nutrients, pesticides and pathogens are transported across the land surface by runoff and through the soil by percolating water. Further, Ritter and Shirmohammadi, (2001) reported that NPS is intermittent, associated very closely with rainfall runoff.

According to Carpenter et al., (1998) out of many sources, major contribution to the NPS is coming from runoff from agriculture including return flow from irrigated agriculture. Agrochemical based intensive agriculture has contributed substantially to the entry of pollutants (excessive nitrogen and phosphorus, pesticide and heavy metals) in to the water bodies and soils (Sun et al., 2012). Approximately 50 to $70 \%$ of water bodies assessed have been found to be adversely affected by agricultural nonpoint source pollution (Ritter and Shirmohammadi, 2001) in Florida, United states.

Up country hilly areas in Sri Lanka such as Nuwara Eliya are popular for intensive exotic vegetable cultivation. As major vegetable providing area in the country, frequent and intensive vegetable cultivation is unavoidable. Excessive and frequent fertilizer application for vegetable cultivation in this area is a common practice (Amarasiri, 1990; Somasiri, 1989). The detrimental impact of higher fertilizer usage on surface and groundwater quality of Sri Lanka was also discussed by Wijewardena (2011). Higher level of Electrical Conductivity and Total Dissolved Solids values of stream water have been recorded in vegetable cultivated areas in highlands and possible reason for the elevated parameters could be the high concentrations of ions species due to fertilizer applications (Amarasekara et al., 2013), manure and liming materials used in farming (Rajakaruna et al., 2005). Further, Amarasekara et al. (2013) reported that higher level of $\mathrm{NO}_{3}-\mathrm{N}$ and $\mathrm{PO}^{3-}$ could also be observed in vegetable cultivated areas compared to other locations in central highlands. Kendaragama et al. (2001) and Sarathchandra, et al. (2013) reported that the soils in up country are having higher $\mathrm{pH}$ in reaction due to high Calcium oxide usage by the farmers prior to cultivation. Even though the Farmers heavily use cattle manure and compost in land preparation, a considerable reduction in organic manure use was observed (Sarathchandra, et al., 2013; Kendaragama et al., 2011) in the cultivated areas due to intensive use of land for agricultural activities with three/ four crops per year.

Riparian buffer zones are considered as environmental management tools for reducing impacts of land use activities on aquatic resources (Parkyn, 2004). Riparian Buffer zones (RBZ) are known to reduce diffuse $\mathrm{N}$ pollution of stream by removing and modifying $\mathrm{N}$ from agricultural runoff (Hefting et al., 2003). Riparian zones are an important transition between terrestrial and aquatic ecosystems, and they function in nutrient cycling and removal (Costello and Lamberti, 2008). Phytoremediation is defined as use of green plants and their associated microbiota, soil amendments, and agronomic techniques to remove, contain, or render harmless environmental contaminants and is the main reaction dominant in the riparian buffer zone (Ke and Tam, 2011) Maintaining a riparian buffer zone would be an option to control NPS pollution.

Therefore, a study was conducted to assess the existing situation of the study area, water sources, agricultural practices, water pollution prevention and management aspects and to investigate the awareness of the farmers about water quality, water pollution and riparian buffer zones in Moon plains and Black pool in Nuwara Eliya. 


\section{MATERIAL AND METHODS}

Randomly selected thirty farmers were surveyed in August 2013 using a semi structured questionnaire including closed and open ended questions. The sample comprised of all vegetable cultivating farmers whose lands are located close proximity to the adjacent water source in the study sites at Moonplain and Black pool in Nuwara Eliya. The information on pesticide and fertilizer usage in different crops, cropping pattern, knowledge about the riparian buffer zone, phytoremediation, and the water quality were investigated.

Surface and groundwater samples were collected 3 times throughout the month of March 2013 representing natural, agricultural landscapes and measured pH, EC (on site), Nitrate and Phosphate (Laboratory) using standard procedures. The gathered data was analysed using MS Excel software and paired t-test was performed using MINITAB 14 to identify whether there are significant differences exist in quality parameters in water draining from different land use/ cover types.

Water sampling points and the locations of available riparian buffers are shown in Figure 1.

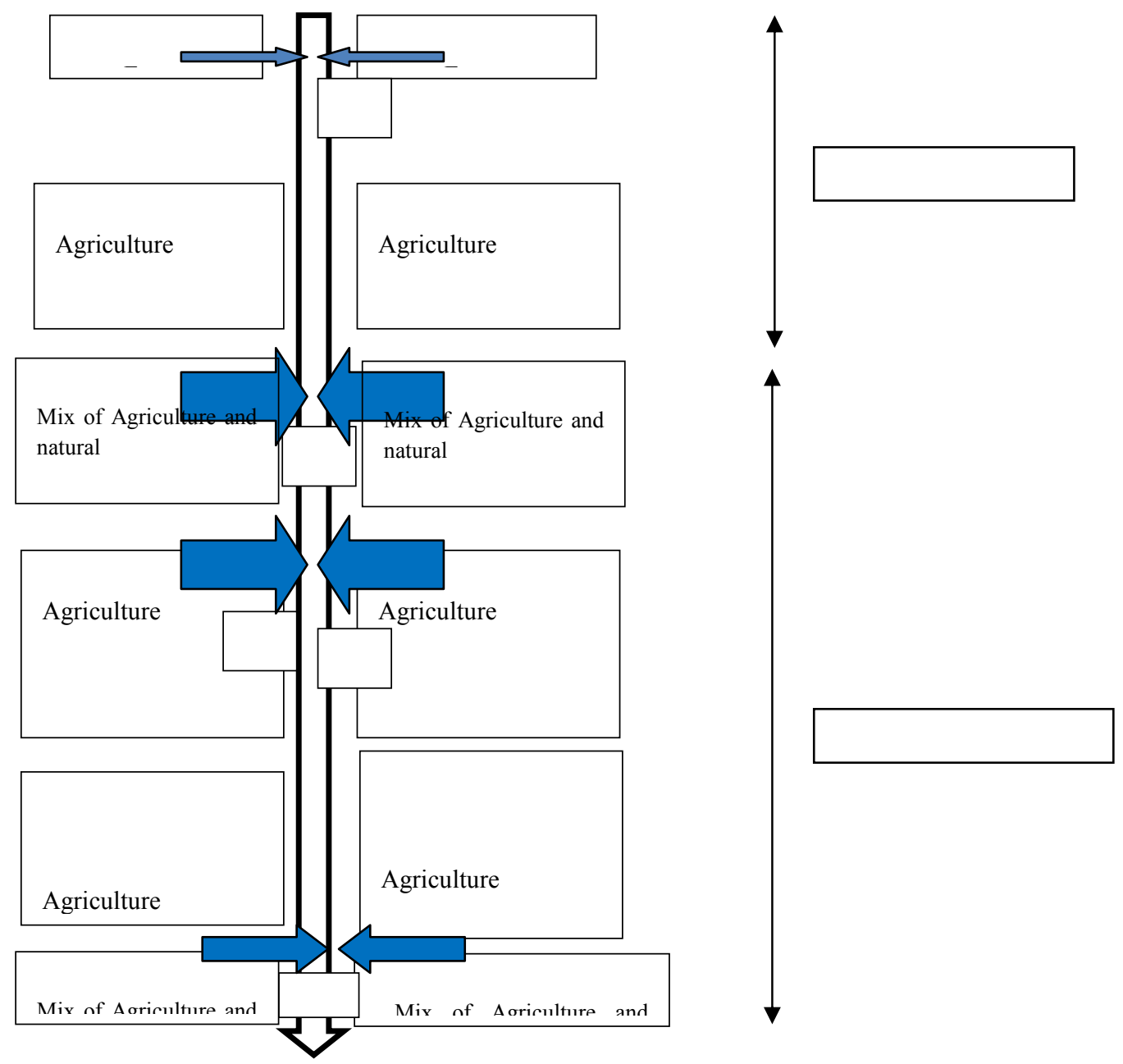


Fig 1. Water Sampling points and availability of the riparian buffer zone in the study area

\section{RESULTS AND DISCUSSION}

(a) Assessing the existing situation of the surveyed area, water sources, agricultural practices

\section{i. Age of farmers}

Out of the selected 30 farmer Sample, 21 were males and nine were female farmers. 11 farmers were in the above 40 age group, in which eight were males and three were females. 10 male and three female farmers were in the age group of 30-40. Only six farmers were belonged to the age group of 20-30. Majority (63\%) of the farmers belong to age group of 30-40 (Table1).

Table1. Composition of the farmers against gender and education level and age

\begin{tabular}{llllll}
\hline \multicolumn{5}{c}{ Educational level } & Total \\
\hline Age group & Degree & Upto A/L & Upto O/L & Upto Grade 8 \\
$\mathbf{2 0 - 3 0}$ & $1 \mathrm{M}$ & $2 \mathrm{~F}, 1 \mathrm{M}$ & $1 \mathrm{M}$ & $1 \mathrm{~F}$ & $\mathbf{3 F}, \mathbf{3 M}$ \\
$\mathbf{3 0 - 4 0}$ & - & $2 \mathrm{M}$ & $2 \mathrm{~F}, 3 \mathrm{M}$ & $1 \mathrm{~F}, 5 \mathrm{M}$ & $\mathbf{3 F}, \mathbf{1 0 M}$ \\
$>\mathbf{4 0}$ & - & $1 \mathrm{M}$ & $2 \mathrm{M}$ & $3 \mathrm{~F}, 5 \mathrm{M}$ & $\mathbf{3 F}, \mathbf{8 M}$ \\
\hline $\mathrm{M}=$ Males & \multicolumn{5}{c}{$\mathrm{F}=$ Females }
\end{tabular}

Henegama et al. (2013) has also revealed similar conditions from her survey in the same study area during 2008 .

\section{ii. Education and gender}

When considering the educational level $50 \%$ of the sample has education level upto grade 8 and majority $(67 \%)$ were male farmers. Twoenty six percent $(26 \%)$ of farmers has educated upto $\mathrm{O} / \mathrm{L}$ and $20 \%$ farmers has reached up to A/Ls. However, only 1 male farmer was a graduate (Table 1). Henegama et al. (2013) revealed that 50\% farmers has obtained the secondary level education, thus they should have knowledge on agricultural pollution and its implication on environment.

\section{iii. Land size and ownership}

In this study area $20 \%$ farm lands were below the extent of 0.04 ha. Land extent of $0.04-0.2$ ha and above 0.2 ha are evenly distributed in the sample which consists a total of $80 \%$. Medium slope lands are dominant in all three land extent categories which consist of $67 \%$ of the sample and steep and flat land distribution was $10 \%$ and $23 \%$ respectively. The slope was measured according to the eye level referencing a flat land. Majority of the lands were farmer owned. However, there are some tenant farmers too.

\section{iv. Cultivation and agrochemical Usage}

During the cropping season, they grow leafy vegetables followed by tuberous vegetables in the immediate next season. The common vegetables cultivated in the area are Carrot (Daucus carota), Leeks (Allium ampeloprasum), Cabbage (Brassica oleracea), Beet Root (Beta vulgaris), Lettuce (Lactuca sativa) and Potato (Solanum tuberosum) (Henegama et al., 
2013; Jayakody, 2002). This was proven by the findings of Henegama et al. (2013). The Farmers tend to use the average rates of MOP, Urea and TSP as $2375 \mathrm{~kg} / \mathrm{ha}, 500 \mathrm{~kg} / \mathrm{ha}$ and $750 \mathrm{~kg} / \mathrm{ha}$ respectively per season. However, Department of Agriculture recommend to apply $330 \mathrm{~kg} / \mathrm{ha}$ Urea, $270 \mathrm{~kg} / \mathrm{ha}$ MOP and $200 \mathrm{~kg} / \mathrm{ha}$ TSP per season (http://www.doa.gov.lk/index.php/en/crop-recommendations/1457) in an average rates to the above mentioned vegetables.

\section{v. Sources of water}

Figure 2 presents the information on drinking and irrigation water sources in the area. Residents in the area use three main drinking water sources namely, shallow wells, pipe borne water and natural springs. Nineteen farmers (64\%) use well water to suffice their drinking water requirement and out of that 16 wells were located at the middle of the field, 2 were on the side of the land and 1 in the compound of the house. Seven famers were using pipe borne water supplied by the National Water Supply and Drainage Board. Natural spring water is the source for 4 families for their drinking water requirements.

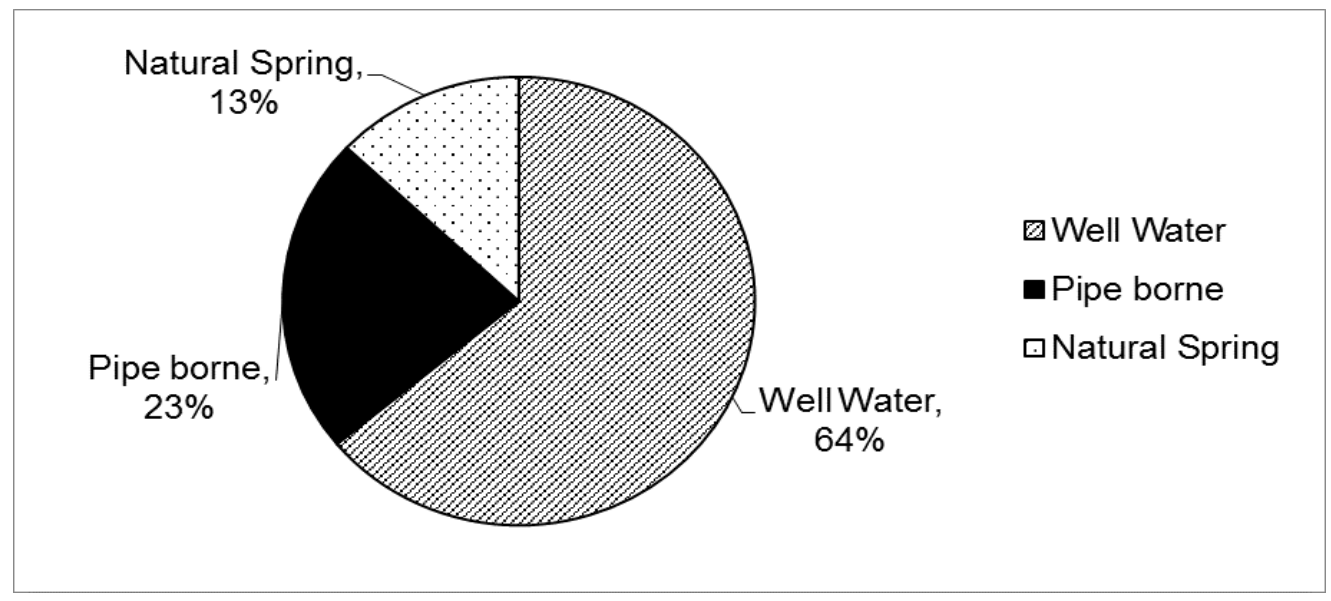

Fig 2. Drinking water sources used by the farmers

\section{(b) Water quality of surface and ground Water}

Water requirements for cultivation was predominantly (83\%) supplied through the irrigation water whereas only $17 \%$ was cultivated through rainfed water. However, Henegama et al. (2013) reported that streams, springs, pipeborne water, ponds, rivers, rainwater are used for irrigation in the area.

The samples were collected representing agricultural land area and natural forest area to invesitgate the water quality parameters namely, Electrical Conductivity, Nitrate, Phosphorus, $\mathrm{pH}$ as tabulated in Table 2.

According to the water sample analysis, high Electrical Conductivity $(151 \mathrm{dS} / \mathrm{m})$ was reported in cultivated area throughout the sampling period compared to the forest area and is most likely due to the application of fertilizer (Amarasekara et al., 2013)., manure and liming ( Rajakaruna et al., 2005). 
Table 2. Average values of water qulity parameters in culivated and natural forest area

\begin{tabular}{|c|c|c|c|c|c|}
\hline & Land use representation & $\begin{array}{l}\mathrm{EC} \\
(\mathrm{dS} / \mathrm{m})\end{array}$ & $\mathrm{pH}$ & $\begin{array}{l}\text { Nitrate } \\
(\mathrm{ppm})\end{array}$ & $\begin{array}{l}\text { Phosphorus } \\
\text { (ppm) }\end{array}$ \\
\hline A & Forest & 29 & 6.1 & 2.41 & 1.17 \\
\hline B & $\begin{array}{l}\text { Mix of natural and agricultural } \\
\text { land use in middle catena }\end{array}$ & 151 & 7.0 & 0.75 & 1.12 \\
\hline C & $\begin{array}{l}\text { Shallow groundwater in an } \\
\text { agricultural land }\end{array}$ & 0.31 & 6.4 & 32.89 & 1.09 \\
\hline $\mathrm{D}$ & Drain in agricultural land & 146 & 6.8 & 8.43 & 1.1 \\
\hline $\mathrm{E}$ & $\begin{array}{l}\text { Mixed land use (Agriculture and } \\
\text { natural land uses in lower catena) }\end{array}$ & 45 & 7.0 & 1.96 & 1.12 \\
\hline
\end{tabular}

Significantly higher amount of nitrate $(32 \mathrm{ppm})$ was reported in shallow groundwater indicating the severity of agriculture-derived water pollution. Leaching of nitrate is the primary reason behind elevated levels of nitrate in shallow groundwater in these agricultural areas (Amarasiri, 2007 and Henegama et al., 2013). However, lower level of $P$ was observed in both vegetable cultivated areas and natural forest. It is said that exotic vegetables are highly P demanding (Amarasekara, et al., 2013) and Tripel Super Phospate is the major P source for intensive vegetable cultivation. According to Dayawansa (2000) this situation occurs due to dilution effect and export of sediment attached phosphate from agricultural land uses comapred to solubale fraction. Addition of soil amendments such as Dolamite $\left(\mathrm{CaCO}_{3}\right)$ (Wjewardena et al., 2001 and Rajakaruna et al., 2005) can be the reason for high $\mathrm{pH}$ levels in the cropping area than forest area in this study area.

\section{(c) Awareness of the farmers about water quality and water pollution}

Out of 30 farmers, majority ( $83 \%$ ) were aware of the water pollution. Awareness on water pollution is high among all age groups. The highest awareness was reported among the age group of 20-30 years. This shows that the young farmers have a considerable level of awareness about water pollution. Education level does not reflect any significant contribution to the awareness on water pollution, However, this could be due to farming knowledge been passed through generations to generation by word of mouth (Senanayake, 2006) which influenced farmers to be mindful on water pollution even though they have not had formal education. Amarasekara et al. (2013) reported that awareness on nutrient pollution was limited among farmers. However, they were aware that chemical usage is the major reason for this situation. Figure 3 presents the reasons for water pollution from the farmers' point of view. 


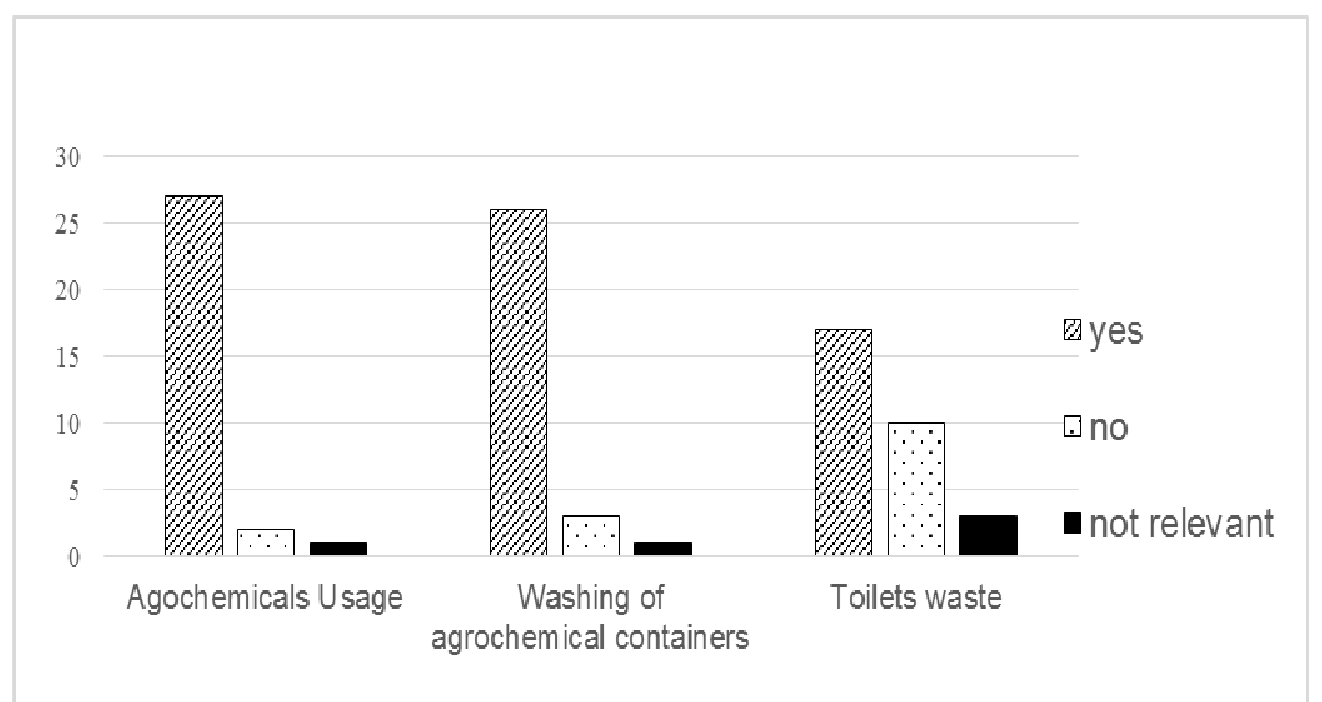

Fig 3. Reasons for water pollution from the farmers' point of view

Almost $99 \%$ of the surveyed farmers were not aware about the water quality and water quality parameters. However, according to Henegama et al. (2013) farmers are aware about the physical changes of drinking water. According to Figure 3, agrochemical and washing of agrochemical containers and toilet wastes are the main reasons for water pollution and findings of Henegama et al. (2013) also confirm this situation.

\section{(d) Relationship between availability of the riparian buffer zone, land extent and water quality}

It is clear that $75 \%$ of the surveyed lands are lack in riparian buffer zone. A stream is passing through 8 lands in which they use that water for cultivation and discharge the drainage back to the stream.

According to Figure 1 riparian buffer zones are available only in E sampling location. However from this study, it is not possible to make conclusions that riparian buffers are effective in managing water pollution.

Table 3. Relationship between availability of the riparian buffer zone and land extent

\begin{tabular}{llll}
\hline \multirow{2}{*}{$\begin{array}{l}\text { Availability of Riparian buffer zone } \\
\text { in the land }\end{array}$} & $<\mathbf{0 . 0 4}$ ha & $\mathbf{0 . 0 4 - 0 . 2}$ ha & $>0.2$ ha \\
& 2 & 4 & 3 \\
Not Available & 2 & 1 & 2 \\
available & 0 & \multicolumn{1}{c}{ Land Extent } \\
\hline
\end{tabular}

\section{(e) Assessing water pollution prevention and management methods}

According to the survey, $83 \%$ responses agreed that self management is the most important to manage and prevent water pollution. About $77 \%$ responses revealed that awareness about water pollution and management practices will be a solution to the problem out of which nearly $73 \%$ of the respondents were aware of riparian buffer zones. Majority of the farmers (57\%) believed that soil conservation can be done by maintaining the riparian buffer zone and $7 \%$ was aware that the riparian buffers can maintain water quality. But $70 \%$ of the 
Farmer fields were cleared and cultivated upto the edge of the land due to limited land availability. This was observed by Amarasekara et al. (2013) and stated that riparian zone of the stream has been cleared and used for intensive vegetable cultivation without adopting proper soil conservation measures in Upper Mahaweli Catchment area.

Table 4. Awareness on riparian buffer zone with education level and age

\begin{tabular}{lllll}
\hline & \multicolumn{4}{c}{ Educational level } \\
\hline Age group & Degree & Upto A/L & Upto O/L & Upto Grade 8 \\
$\mathbf{2 0 - 3 0}$ & $100 \%$ & $33.3 \%$ & $100 \%$ & $0 \%$ \\
$\mathbf{3 0 - 4 0}$ & - & $50 \%$ & $60 \%$ & $66.7 \%$ \\
$>\mathbf{4 0}$ & - & $100 \%$ & $100 \%$ & $75 \%$ \\
\hline
\end{tabular}

Awareness on riparian buffer zone as water pollution control remedy is higher in all educational groups in $>40$ age group. According to the farmers, there is no advice given to them about the riparian buffer zones and their usefulness by the government or nongovernmental organizations. This revealed that there should be a proper communication mechanism to convey the usefulness of maintaining riparian buffer zones in the field in view of protecting stream water quality. This was stated in Henegama et al. (2013) also. Therefore, proper institutional engagement is an essential and current need in managing water pollution.

However, due to shortage of land, $43 \%$ of the Farmers did not like to maintain the riparian buffer zone even after explaining the importance of it and remaining $57 \%$ of the Farmers like only to allocate $0.5 \mathrm{~m}-1.0 \mathrm{~m}$ land as the riparian buffer zone. Thirty percent ( $30 \%$ ) of the farmer fields were consisted with riparian buffer zone but the farmer who has educated upto degree level even has not allocated the riparian buffer zone. Out of surveyed sample 14 (47\%) farmers were aware about the phytoremediation as excess nutrient absorption by the plants. They have recognized Cannas (Canna indica L.), Water Cress (Nastratum officinale), Arum Lily (Zanteseschia aethiopica) as phytoremediating plants. The knowledge about the phytoremediation is dispersed in all age groups irrespective of the educational level.

\section{CONCLUSIONS}

Majority of the farmers were males and belonged to the age group 30-40 years. Eighty percent of the land extent varied between 0.04 ha and above 0.2 ha out of which $67 \%$ were in medium slopes. Majority of the lands were owned by the farmers. Irrigation water requirement is mainly supplied through surface water. Majority $(83 \%)$ was aware of the water pollution and knowledge is transferred via generations and not by the education. Higher Electrical Conductivity was reported in cultivated area due to application of fertilizer, manure and lime. Higher amount of nitrate in shallow groundwater was measured due to leaching of nitrate. Nearly $73 \%$ of the respondents were aware on riparian buffer zone as the soil conservation method but not as the water quality improvement method. However, due to landlessness $43 \%$ of the Farmers did not like to maintain the riparian buffer zone, therefore, capacity building, proper farmer awareness on water pollution and need of maintaining a riparian buffer to protect water resources are essential. 


\section{REFERENCES}

Amarasekara, M.G.T.S., Dayawansa, N.D.K., and De Silva, R.P. (2013). Stream Water Quality depletion under intensive agriculture. Journal of South Asian Water studies, 4:1: pp23-37.

Amarasiri, S. (2007). Declining Water Quality and its effect on Water Security, In Water Resources Research in Sri Lanka, De Silva R. P. and Dayawansa, N.D.K.(Ed.) symposium proceedings of the Water Professionals' Day, Geo- Informatics Society of Sri Lanka, pp 110.

Amarasiri, S.L. (1990). Phosphorus management in intensive vegetable cultivation: in Phosphorus requirements for sustainable Agriculture in Asia and Oceania, pp 453-460.

Carpenter, S.R., Caraco, N.F., Correl, D.L., Howarth, R.W., Sharpley, A.N., and Smith, V.H. (1998). Nonpoint pollution of surface waters with phosphorus and Nitrogen. Technical report, Ecological applications, 8(3), pp 559-568.

Costello, D. and Lamberti, G. (2008). Non-native earthworms in riparian soils increase nitrogen flux into adjacent aquatic ecosystem. OECOLOGIA, 15893): pp 499-510.

Dayawansa, N.D.K. (2002). The development of nutrient pollution models for use at the catchment scale. $\mathrm{PhD}$ thesis (unpublished), University of Newcastle.

Fertilizer recommendation for crops, [Accessed on 10.08.2016]. Available at http://www.doa.gov.lk/index.php/en/crop-recommendations/1457,

Hefting, M.M., Bobbink, R. and Caluwe, H.D. (2003). Nitrous Oxide emission and denitrification in chronically nitrate loaded Riparian buffer zones. Journal of Environmental Quality, 32: pp 1194-1203.

Henegama, H.P., Dayawansa, N.D.K. and De Silva, S. (2013). An Assessment of Social and Environmental Implications of Agricultural Water Pollution in Nuwara Eliya. Tropical Agricultural Research, 24: (4) : pp 304-316.

Jayakody, A.N. (2002). Soil fertility and nutrient contamination of water in a hilly catena of Sri Lanka under intensive cropping. $17^{\text {th }}$ WCSS, Thailand.

Ke, L. and Tam, N.F.Y. (2011). Phytoremediation using Mangrove Wetlands: Mechanisms and Application Potential. Handbook of Phytoremediation:Nova Science Publisher: pp 415442.

Kendaragama, K.M., Lathiff, M.A. and Chandrapala, A.G. (2001). Impact of vegetable cultivation on fertility status of soils in the Nuwara Eliya Area. Annals of the Sri Lanka Department of Agriculture, 3: pp 95-100.

Luzio, M.D., Srinivasan, R. and Arnold, J.G. (2004). A GIS coupled hydrological model system for the Watershed Assessment of Agricultural Nonpoint and Point Sources of Pollution. Transactions in GIS, 2004, 8(1): pp 113-136. 
Mendelker, D.R., (1989). Controlling nonpoint source water pollution: Can it be done?. Chicago -Kent law review. Symposium on prevention of groundwater contamination in the Great Lakes Region,65: 2: pp 479-502.

Neary, D. G., Swank, W.T., and Riekerk, H. (1989). An overview of non point source pollution in the Southern United States.

http://coweeta.uga.edu/publications/publications/5th\%20group/pdf/621.pdf, accessed $13^{\text {th }}$ January, 2016.

Parkyn, S. (2004). Review of Riparian Buffer Zone effectiveness. NIWA ( National Institute of Water and Atmospheric Research) MAF Technical paper No;2004/05.

Rajakaruna, R.M.P., Nandasena, K.A., and Jayakody, A.N. (2005). Plant nutrient Contamination of shallow groundwater in intensive Vegetable Gardend of Nuwara Eliya. Tropical Agricultural Research, 17: pp 80-92

Ritter, W.F. and Shirmohammadi, A. (2001). Agricultural nonpoint source pollution: Watershed management and hydrology. Boca Raton, Florida: CRC Press.

Sarathchandra, K.D.M.S.S., Dayawansa, N.D.K., and Mowjood, M.I.M. (2013). Assessment of impact on soil and water by fertilizer usage in intensively cultivated areas in Nuwara Eliya, Sri Lanka. $2^{\text {nd }}$ Sri Lankan Round Table on Sustainable cleaner Production, 2013.

Senanayake, S.G.J.N. (2006). Indigenous knowledge as a key to sustainable development. The journal of Agricultural Sciences, 2(1), pp 87-94.

Somasiri, S. (1989). Management and utilization of acid soils in Sri Lanka: in Management of Acid Soils in the Humid Tropics of Asia, pp 90-99.

Sun, B., Zhang, L., Yang, L., Zhang, F., Norse, D. and Zhu, Z. (2012). Agricultural NonPoint Source Pollution in China: Causes and Mitigation Measures. Royal Swedish Academy of Sciences, 41: pp 370-379.

Wijewardena, J.D.H., Yapa, U.W.S.P. and Yatagama, S.M.K.G. (2001). Drinking water quality of some wells in the intensive vegetable growing lands in the up country wet Zone. Journal of Soil Science Society Sri Lanka, 13: pp 14-21.

Wijewardena, J.D.H. (2011). Agriculture and water pollution in Sri Lanka. In Dayawansa, N.D.K. and De Silva, R.P. (Ed.), Proceedings of the Water Professionals' Day Symposium on Water Resources Research in Sri Lanka, pp 3-17. 